Article

\title{
Water Age Effects on the Occurrence and Concentration of Legionella Species in the Distribution System, Premise Plumbing, and the Cooling Towers
}

\author{
Alshae R. Logan-Jackson ${ }^{1, *}$ D and Joan B. Rose ${ }^{2}$ \\ 1 Department of Microbiology and Molecular Genetics, Michigan State University, East Lansing, MI 48824, USA \\ 2 Department of Fisheries and Wildlife, Michigan State University, East Lansing, MI 48824, USA; \\ rosejo@msu.edu \\ * Correspondence: loganals@msu.edu
}

check for updates

Citation: Logan-Jackson, A.R.; Rose, J.B. Water Age Effects on the Occurrence and Concentration of Legionella Species in the Distribution System, Premise Plumbing, and the Cooling Towers. Microorganisms 2022, 10, 81. https://doi.org/10.3390/ microorganisms10010081

Academic Editors: Teresa Fasciana, Anna Giammanco and Mario Palermo

Received: 1 December 2021

Accepted: 29 December 2021

Published: 31 December 2021

Publisher's Note: MDPI stays neutral with regard to jurisdictional claims in published maps and institutional affiliations.

Copyright: (c) 2021 by the authors. Licensee MDPI, Basel, Switzerland. This article is an open access article distributed under the terms and conditions of the Creative Commons Attribution (CC BY) license (https:// creativecommons.org/licenses/by/ $4.0 /)$.

\begin{abstract}
In this study, droplet digital $\mathrm{PCR}^{\mathrm{TM}}\left(\mathrm{ddPCR}^{\mathrm{TM}}\right)$ was used to characterize total Legionella spp. and five specific Legionella species from source (groundwater) to exposure sites (taps and cooling towers). A total of 42-10 L volume water samples were analyzed during this study: 12 from a reservoir (untreated groundwater and treated water storage tanks), 24 from two buildings (influents and taps), and six from cooling towers, all part of the same water system. The approximate water age (time in the system) for all sample locations are as follows: $\sim 4.5,3.4,9.2,20.8$, and $23.2 \mathrm{~h}(\mathrm{~h})$ for the groundwater to the reservoir influent, reservoir influent to the reservoir effluent, reservoir effluent to building Fa (building names are abbreviated to protect the privacy of site location), building ERC and the cooling towers, respectively. Results demonstrated that gene copies of Legionella spp. (23S rRNA) were significantly higher in the cooling towers and ERC building $(p<0.05)$ relative to the reservoir and building $\mathrm{Fa}$ (closest to reservoir). Legionella spp. (23S rRNA) were found in 100\% (42/42) of water samples at concentrations ranging from 2.2 to $4.5 \log 10 \mathrm{GC} / 100 \mathrm{~mL}$. More specifically, L. pneumophila was found in $57 \%(24 / 42)$ of the water samples, followed by L. bozemanii $52 \%$ (22/42), L. longbeachae $36 \%(15 / 42)$, L. micdadei $23 \%(10 / 42)$ and L. anisa $21 \%(9 / 42)$ with geometric mean concentrations of 1.7, 1.7, 1.4, 1.6 and $1.7 \log _{10} \mathrm{GC} / 100 \mathrm{~mL}$, respectively. Based on this study, it is hypothesized that water age in the distribution system and the premise-plumbing system as well as building management plays a major role in the increase of Legionella spp., (23S rRNA) and the diversity of pathogenic species found as seen in the influent, and at the taps in the ERC building-where the building water quality was most comparable to the industrial cooling towers. Other pathogenic Legionella species besides L. pneumophila are also likely amplifying in the system; thus, it is important to consider other disease relevant species in the whole water supply system-to subsequently control the growth of pathogenic Legionella in the built water environment.
\end{abstract}

Keywords: Legionella pneumophila; Legionella longbeachae; Legionella bozemanii; Legionella micdadei; Legionella anisa; water age; building water quality

\section{Introduction}

Legionella was first described and classified over 40 years ago [1,2]. Since its discovery, there have been 61 identified Legionella species [3], of which 28 have been isolated from human specimens associated with disease [3]. Legionella pneumophila serogroup 1 is the most well-known and studied Legionella species, as it is most often identified as the etiologic agent of Legionnaires' Disease. Legionella pneumophila accounts for more than $90 \%$ of Legionnaires' Disease cases [4,5] followed by L. micdadei, L. bozemanii, and L. longbeachae while other species such as L. anisa are rarely found to cause disease [6-9].

Currently, in the United States (U.S.), the incidence rate of Legionnaires' Disease is increasing with an annual rate of $550 \%$, corresponding to a range of 0.4 to 2.2 reported cases per 100,000 population from 2000 to 2017 [10]. Legionella pneumophila is the cause of 
most drinking water disease outbreaks in contrast to other water-related pathogens in the U.S. [11].

A large percentage of the U.S. population gets its drinking water from groundwater [12]. In the U.S., groundwater withdrawal for public supply accounts for approximately $39 \%$ of the total usage [12]. Even in Michigan surrounded by the Great Lakes, total groundwater usage is about 700 million gallons per day [13]. Moreover, there is an estimation of 1.7 million people in Michigan that rely on municipal water supplies utilizing groundwater as their primary drinking water source [13]. In groundwater, Legionella has been found in several studies to range in concentrations from $10^{1}$ to $10^{4} \mathrm{CFU} / 100 \mathrm{~mL}$ [14-17]. Groundwater sources are notorious for having iron concentrations, and this may be considered problematic [18] as iron is a micronutrient for the growth of Legionella [19].

Legionella bacteria are known to colonize engineered water systems such as premise plumbing, and cooling towers $[20,21]$. For example, L. pneumophila serogroup 1 occurred more than once in $7 \%(5 / 68)$ of cold water taps at various concentrations by a PCR method [20]. Legionella spp. have also occurred in 39\% (78/196) of cooling towers samples collected, 27\% (53/196) and 20\% (40/196) of which were L. pneumophila and L. pneumophila serogroup 1, respectively [21]. In these environments, Legionella can be aerosolized and potentially inhaled from showers, faucets, hot tubs/swimming pools, and cooling towers [22]. However, there are only a few limited studies on specific pathogenic Legionella species other than L. pneumophila in drinking water supply systems and cooling towers. For example, there has been a characterization study of pathogenic Legionella species in hot water systems by MALDI-TOF and 17 Legionella species were identified. However, there were only two species that were mostly identified, L. pneumophila (identified isolates: $40,234 / 47,924)$ and L. anisa (identified isolates: 4307/47,924) [23]. Among the 2685 and 877 warm water installations that were positive with L. pneumophila and L. anisa, 13\% $(377 / 2685)$ and $30 \%(266 / 877)$ of the samples co-occurred with other Legionella species, respectively [23]. Another study detected Legionella species in kitchen sinks in private residences and restroom sinks in public buildings by PCR amplification and sequencing and the frequently detected species were L. pneumophila, L. fairfieldensis, and L. dresdeniensis [24]. Lesnik et al., 2016 [25] evaluated pathogenic Legionella species in a drinking water supply system by single-stranded conformation polymorphism and the most-abundant phylotypes were L. pneumophila and L. longbeachae. However, both studies [24,25] did not specifically detail the proportion of the samples that were L. pneumophila and non-L. pneumophila-the authors showed the phylogenetic relatedness of Legionella genus specific species. Thus, it was not possible to determine the co-occurrence of L. pneumophila and non-L. pneumophila species in individual, specific samples. Recently, Tsao et al. (2019) [26] also evaluated pathogenic Legionella species in cooling towers using 16 and 18S rRNA gene amplicon sequencing and out of $100 \%$ relative abundance, the frequently detected were $L$. rowbothamii $(0.060 \%)$ and L. worsleiensis $(0.030 \%)$; this study investigated the co-occurrence by the bacterial phlya but not by the species level. Llewellyn et al. [21] also detected multiple Legionella species in cooling towers by culture, and out of 144 Legionella isolates, the most common species were L. pneumophila (53\%), L. anisa (22\%), and L. rubrilucens (9\%) [21]. Pereira et al. (2017) [27] evaluated pathogenic Legionella species in cooling towers using universal primers 16S rRNA (PCR) and genus-specific deep sequencing (next-generation sequencing) and out of $100 \%$ relative abundance, the most frequently detected species were L. anisa $(19.2 \%)$, L. micdadei $(18.5 \%)$, and L. pneumophila $(18.4 \%)$. While both studies $[21,27]$ described the proportion of the samples that were positive for L. pneumophila relative to non-L. pneumophila, neither author described the co-occurrence of L. pneumophila and non-L. pneumophila in any given sample. Logan-Jackson et al., 2021 [28] investigated several pathogenic Legionella species in a complete water supply system. However, the ecology of L. pneumophila and non-L. pneumophila species in individual, specific samples were not discussed. The focus of Logan-Jackson et al., 2021 [28] was on understanding the co-occurrence of five of the most-disease relevant Legionella species to free-living amoebae, Naegleria and Acanthamoeba. The improvement of this study to the studies discussed above 
is investigating only Legionella ecology in a complete water supply system (from source to tap) and describing how multiple factors (water age, water quality parameters, etc.) contributes to its occurrence and concentration.

The goal of this study was to detect and quantify five pathogenic Legionella species from a groundwater system including exposure sites such as taps and cooling towers. This study examined the ecology of disease-relevant strains of Legionella from the source and treated water system. The following objectives were pursued: (i) quantification of total Legionella spp. (23S rRNA), L. pneumophila, L. anisa, L. longbeachae, L. micdadei, and L. bozemanii in groundwater coming in and out of a reservoir (untreated and treated water storage tanks), the influent pipe at two buildings, the hot and cold-water taps (collected separately) and cooling towers and (ii) exploration of the associations of Legionella species with respect to location, temperature, chlorine, conductivity, $\mathrm{pH}$, Heterotrophic Plate Count (HPC), and water age.

\section{Materials and Methods}

\subsection{Site Location and Sampling}

Forty-two water samples were collected during July, August, and September of 2019 from the reservoir (untreated and treated water storage tanks), two academic/research buildings ( $\mathrm{Fa}$, and $\mathrm{ERC})$, and six cooling towers on a research-intensive university campus that runs its own water system. The reservoirs were two different standing storage tanks that contained un-chlorinated water and chlorinated water. Thus, the building water supply secondary disinfectant was free chlorine. The reservoir and cooling towers were sampled six times and the buildings were sampled three times; each sampling replicate were collected on different days. The untreated and treated water storage tanks were referred to as RES_IN and RES_EF, respectively. At the time of sampling, buildings Fa and ERC construction years were 1948 and 1986, respectively. The pipe material for building Fa $75 \%$ galvanized and $25 \%$ copper. Building ERC pipe material was $50 \%$ galvanized and $50 \%$ copper. The average monthly water usage (five- year average) and distance from the effluent pipe of the reservoir for building Fa were 172,993 L/month and $4.7 \mathrm{~km}$ and for building ERC were 738,533 L/month and $19.4 \mathrm{~km}$. The building size for building Fa was $7118 \mathrm{~m}^{2}$ with two floors and for building ERC was $11,896 \mathrm{~m}^{2}$ with one floor. The building name description of each building was abbreviated to protect the privacy of the site location. The water samples collected for this study are the same samples from Logan-Jackson et al., 2021 and some of these results in Tables 1 and 4 are available from a previously published paper [28].

A ten-liter grab or composite sample was collected from each location to obtain water that was coming directly from untreated ground water, treated (disinfected) water, buildings influent pipe and potable water, and cooling towers. The groundwater source had $\sim 20$ production wells, which are completed at a depth of approximately 435 feet. The wells drew water from an aquifer and the un-treated ground water is delivered directly to an untreated storage tank. The influent reservoir pipe (RES_IN) seeds water into another storage tank, where the water is treated before pumped to the buildings. The water treatment was solely chlorine. The effluent reservoir pipe (RES_EF) distributes water into the buildings service lines and cooling towers on a university campus. Water was collected from the source to tap to understand how the water age impacts the microbial occurrence and concentration. The water age in this study is presented as hours and it is defined as follows: the time from the ground water wells to RES_IN (4.5 h), RES_IN to RES_EF (3.4 h), RES_EF to the influent pipe of building Fa and ERC ( $9.2 \mathrm{~h}$ and $20.8 \mathrm{~h}$, respectively), and the cooling towers $(23.2 \mathrm{~h})$.

Ten liters of grab sample were collected from the RES_IN and RES_EF, both building's influent, as well as from the cooling towers. RES_IN and RES_EF samples were collected directly from the influent and effluent pipes of the reservoir, respectively. Both building's influent samples were collected directly from the buildings service lines. For the buildings (Fa and ERC) cold- and hot-water potable samples, $10 \mathrm{~L}$ composite sampling was based on 
the number of taps per floor. The building composite samples comprised of the first draw samples from all locations investigated. The reasoning behind this sampling scheme was to determine the percent positive for the entire building and not a single location in the building. The point of use sample locations were sink faucets and showerheads. Building Fa had two floors with two and three sinks on the first and second floor, respectively. ERC had one floor with 11 sinks and two shower sampling locations. The cold and hot-water faucets were composited separately to evaluate the different water systems. For the potable water samples, building Fa had 2-10 L composite samples per floor (4-10 L composite samples total), while ERC only had 2-10 L composite samples total. To make a total of 4-10 L composite samples in building Fa, 5- and 3.3-L composite samples were collected on floors one and two, respectively. The reason buildings Fa and ERC had 4- and 2-10 L composite samples were to determine the building by compositing the tap (cold and hot) per floor, if any. To composite $10 \mathrm{~L}$ in building ERC, $0.77 \mathrm{~L}$ of water was collected from each cold and hot water point of use, separately. Each carboy contained $10 \mathrm{~mL}$ of $10 \%$ sodium thiosulfate to neutralize residual chlorine. Per sampling day, building Fa had a total of five samples: one for the influent sampling location and four composite samples (coldand hot-water). Per sampling day, building ERC had a total of three samples: one for the influent sampling location and two composite samples (cold- and hot-water). There were several cooling towers on the research institution, including on the top of buildings and the power plant, but it was decided to only sample six cooling towers from the power plant. In detail, 12 samples were collected from the reservoir (six, RES_IN and six, RES_EF), 15 from building $\mathrm{Fa}$, nine from building ERC, and six from the cooling towers, all replicates were collected on different days.

\subsection{Chemical-Physical and Microbiological Analysis}

A $300 \mathrm{~mL}$ sample was collected for physiochemical parameters. During sampling, the temperature and chlorine residuals (total and free) were measured using calibrated thermometers and the Test Kit Pocket Colorimeter II $\left(\mathrm{HACH}^{\circledR}\right.$, Loveland, CO, USA) according to the manufacturer's instructions. After sampling, conductivity, $\mathrm{pH}$, and turbidity were measured at the laboratory according to the manufacturers' instructions using a Russell RL060C Portable Conductivity Meter (Thermo Scientific, Waltham, MA, USA), UltraBasic pH meter (Denver Instrument, Bohemia, NY, USA), and a Turbidity Meter code 1970-EPA (LaMottee Company, Chestertown, MD, USA). Conductivity is an important measurement to determine the impurity level of dissolved substances, chemicals and minerals, and $\mathrm{pH}$ is an important indicator to determine how the water is changing chemically. Turbidity is a critical measurement that determines the clarity of a water sample. After collecting the water samples, all samples were placed on ice and transported to the laboratory and immediately processed for ultrafiltration (described below) and HPCs. HPC is a procedure for measuring live bacteria in water samples; it helped to measure the changes in culturable bacteria from source to tap. All samples were tested for HPC analyses using membrane filters ( $47 \mathrm{~mm}$ diameter, $0.45 \mu \mathrm{m}$ pore size; PALL Corporation, Port Washington, NY, USA) on m-HPC agar (Becton, Dickinson and Company, Difco, Detroit, MI, USA). The plates were incubated for $48 \pm 2 \mathrm{~h}$ at $37^{\circ} \mathrm{C}$, then enumerated for colony-forming units. In addition to HPCs, all samples were also tested for total and fecal coliforms using Colilert (IDEXX Laboratories, Westbrook, ME, USA).

\subsection{Water Sample Processing}

All 42-10 L samples were processed using a single Asahi REXEED-25S dialysis filter (Dial Medical Supply, Chester Springs, PA, USA). Each filter was pretreated with $0.01 \%$ of sodium hexametaphosphate-used to trap microbial material onto the filters. Each filter was used in a dead-end ultrafiltration approach. A high-pressure single-use elution fluid canister (INNOVAPREP LLC, Drexel, MO, USA) was used to concentrate the $10 \mathrm{~L}$ to $\sim 50 \mathrm{~mL}$, and each ultrafiltration concentrate was split into several $10 \mathrm{~mL}$ subsamples 
for preservation— to reduce the need for several freeze/thaw cycles. There were 5-10 mL subsamples.

\subsection{DNA Extraction and Quantitative Detection of Legionella Species Using Droplet Digital PCR}

Each $10 \mathrm{~mL}$ subsample (one/sample) was filtered on to a polycarbonate filter $(47 \mathrm{~mm}$ diameter, $0.45 \mu \mathrm{m}$ pore size; Whatman, Kent, UK) inside of a sterilized $47 \mathrm{~mm}$ diameter magnetic filter funnel (PALL Corporation, Port Washington, NY, USA). The filter containing the environmental contents was then transferred to a 2.0-mL polypropylene screw cap tube (VWR, Radnor, PA, USA) containing $0.3 \mathrm{~g}$ of 212-300 $\mu \mathrm{m}$ acid-washed glass beads (Sigma, St. Louis, MO, USA) for DNA extraction. DNA was extracted by adding $590 \mu \mathrm{L}$ of AE buffer (Qiagen, Hilden, Europe) to each screw-cap tube. The filters with the glass beads were then bead milling using a FastPrep-24 ${ }^{\mathrm{TM}} 5 \mathrm{G}$ Instrument MP Biomedicals (VWR). Each sample was milled at $6000 \mathrm{rpm}$ for one minute, followed by centrifugation at $12,000 \times g$ for one minute. The supernatant $(\sim 400 \mu \mathrm{L})$ was then transferred to a new sterilized microcentrifuge tube and centrifuged at $12,000 \times g$ for three minutes to pellet any remaining debris. Extracted DNA was eluted $(\sim 350 \mu \mathrm{L})$ into a final sterilized microcentrifuge tube. The eluted DNA was aliquoted into five subsamples which contained $\sim 60 \mu \mathrm{L}$ of the eluted nucleic acid and stored at $-80^{\circ} \mathrm{C}$. Aliquoting the eluted DNA help to reduce the need for several freeze/thaw cycles in the event the sample needed to be re-ran. One aliquot per water sample was later used for PCR analysis (ddPCR analysis occurred within 30 days of extraction). Ten milliliters of phosphate-buffer water were filtered and functioned as a filtration blank.

Droplet digital PCR technology was performed according to the manufacturer's instructions to analyze each sample for Legionella. All positive controls were obtained from American Type Culture Collection (ATCC, Manassas, VA, USA). Each sample was analyzed for Legionella spp. (23S rRNA), and five pathogenic species (L. pneumophila [ATCC No. 33152], L. anisa [ATCC No. 35292], L. micdadei [ATCC No. 33218], L. bozemanii [ATCC No. 33217], and L. longbeachae [ATCC No. 33462]). All primers and probes were ordered from Eurofins Genomics co. (Louisville, KY, USA). The primers and probes used in this study are listed in Supplementary Materials Table S1. Per assay, there was one ddPCR run with triplicate biological (sample collection) and technical replicates (same extraction). Three duplex reactions were performed for this study: the first assay comprised of Legionella spp. (23S rRNA) and L. pneumophila; the second assay consisted of L. micdadei and L. anisa; the third assay contained L. bozemanii and L. longbeachae. For each assay: sterilized molecular grade-water (without template) served as a no-template control to detect environmental contamination and phosphate-buffer water (PBW) functioned as an experimental control, this helps to determine if the PBW introduced contamination. There were five microbial DNA positive controls: L. pneumophila, L. micdadei, L. anisa, L. bozemanii, and L. longbeachae used to verify the efficiency of the assay. The negative and positive controls listed above served as experimental controls. Sample results were only considered for analysis when the reader accepted 10,000 or more droplets as part of the quality control, and unknown samples with three or more positive droplets per well were considered a true positive. The limit of detection for the assays were $1.3 \log$ per $100 \mathrm{~mL}$. Legionella species were detected and quantified when the value was at or above $1.3 \log$ per $100 \mathrm{~mL}$. Specific details of ddPCR and the definition of the limit of detection and quantification is presented in the Supplementary Information.

Each amplification ddPCR reaction mixture consisted of $2 X$ supermix (no dUTP) (BioRad Laboratories, Hercules, CA, USA), mixed with a final concentration of $900 \mathrm{nM}$ forward and reverse primers and $250 \mathrm{nM}$ probes and up to $330 \mathrm{ng}$ of DNA template in a final volume of $20 \mu \mathrm{L}$. Droplets were generated according to the manufacturer's instructions using a QX200 Droplet Generator. Endpoint PCR was performed in a T100 Thermal Cycler (Bio-Rad Laboratories, Hercules, CA, USA) and the cycling protocol was as follows: $95^{\circ} \mathrm{C}$ for $10 \mathrm{~min}$, followed by 40 cycles of $94{ }^{\circ} \mathrm{C}$ for $30 \mathrm{~s}$ and $57^{\circ} \mathrm{C}$ for $1 \mathrm{~min}$ with a final 10 min cycle at $98^{\circ} \mathrm{C}$ 
for $10 \mathrm{~min}$. The plate was then cooled for $\sim 30 \mathrm{~min}$, and droplets were then read using a QX200 droplet reader (Bio-Rad QX200 ${ }^{\mathrm{TM}}$ Droplet Digital PCR System, Hercules, CA, USA).

\subsection{Statistical Analysis}

Descriptive statistics were conducted in GraphPad Prism 8 software (GraphPad Software, San Diego, CA, USA). Statistical analysis, including One-way ANOVA, Pearson Correlation, and simple linear regression, were used to determine the significance of the findings. The biological data were expressed as the geometric mean with geometric deviation, and chemical data were shown as arithmetic means with standard deviation. A geometric mean for each sample was calculated using all values from technical and biological replicates. Sample concentrations were transformed from gene copies (GC)/100 mL into $\log _{10} \mathrm{GC} / 100 \mathrm{~mL}$ for statistical analysis [28]. Statistical results were interpreted at the level of significance $p<0.05$.

\section{Results}

\subsection{Characterization and Concentrations of Legionella $23 S$ rRNA and Five Pathogenic} Legionella Species

Legionella spp. (23S rRNA) was found in 100\% (42/42) of water samples at concentrations ranging from 2.2 to $4.5 \log _{10} \mathrm{GC} / 100 \mathrm{~mL}$. Legionella pneumophila was found in $57 \%(24 / 42)$ of the water samples, followed by L. bozemanii $52 \%$ (22/42), L. longbeachae $36 \%$ $(15 / 42)$, L. micdadei $23 \%(10 / 42)$, L. anisa $21 \%(9 / 42)$ at geometric mean concentrations of $1.7,1.7,1.4,1.6$ and $1.7 \log _{10} \mathrm{GC} / 100 \mathrm{~mL}$, respectively (Table 1). Some of the results in Table 1 are also available in a previously published paper [28]. Table 1 is adapted with permission from ref. [28]. (2021, Alshae, R. Logan-Jackson).

Table 1. Geometric mean concentrations of general Legionella (23S rRNA) and five specific Legionella species collected from the drinking water system (RES_IN, RES_EF, Fa_IN, Fa_Taps, ERC_IN, ERC_Taps) and the cooling towers (CT).

\begin{tabular}{|c|c|c|c|c|c|c|c|}
\hline $\begin{array}{l}\text { Legionella } \\
\text { Species }^{b}\end{array}$ & CТ $(n=6)$ & $\begin{array}{l}\text { ERC Taps } \\
\text { (Cold } n=3 \text { ) } \\
{[\text { Hot } n=3]}\end{array}$ & ERC_IN $(n=3)$ & $\begin{array}{c}\text { Fa_Taps } \\
\text { (Cold } n=6) \\
{[\text { Hot } n=6]}\end{array}$ & $\begin{array}{l}\text { Fa_IN } \\
(n=3)\end{array}$ & Res_EF $(n=6)$ & Res_In $(n=6)$ \\
\hline $\begin{array}{c}\text { Legionella spp. } \\
\text { (23S rRNA) } \\
(\%+) \\
{[\%+]}\end{array}$ & $\begin{array}{l}100 \% \\
(6 / 6)\end{array}$ & $\begin{array}{l}(100 \%: 3 / 3) \\
{[100 \%: 3 / 3]}\end{array}$ & $\begin{array}{l}100 \% \\
(3 / 3)\end{array}$ & $\begin{array}{l}(100 \%: 6 / 6) \\
{[10 \%: 6 / 6]}\end{array}$ & $\begin{array}{l}100 \% \\
(3 / 3)\end{array}$ & $\begin{array}{l}100 \% \\
(6 / 6)\end{array}$ & $\begin{array}{l}100 \% \\
(6 / 6)\end{array}$ \\
\hline $\begin{array}{c}\text { Legionella spp. } \\
(23 \mathrm{r} \text { rRA) } \\
\text { Geomean (Log } \\
\left.{ }_{10} \mathrm{GC} / 100 \mathrm{~mL}\right)\end{array}$ & 4.5 & $\begin{array}{l}(4.5) \\
{[4.4]}\end{array}$ & 4.0 & $\begin{array}{l}(2.6) \\
{[2.2]}\end{array}$ & 2.2 & 2.7 & 3.1 \\
\hline $\begin{array}{c}\text { L. pneumophila } \\
(\%+) \\
{[\%+]}\end{array}$ & $\begin{array}{r}83 \% \\
(5 / 6)\end{array}$ & $\begin{array}{c}(100 \%: 3 / 3) \\
{[0 \%: 0 / 3]}\end{array}$ & $\begin{array}{r}33 \% \\
(1 / 3)\end{array}$ & $\begin{array}{l}(33 \%: 2 / 6) \\
{[33 \%: 2 / 6]}\end{array}$ & $\begin{array}{l}67 \% \\
(2 / 3)\end{array}$ & $\begin{array}{l}83 \% \\
(5 / 6)\end{array}$ & $\begin{array}{l}83 \% \\
(5 / 6)\end{array}$ \\
\hline $\begin{array}{l}\text { L. pneumophila } \\
\text { Geomean (Log } \\
{ }_{10} \mathrm{GC} / 100 \mathrm{~mL} \text { ) }\end{array}$ & 2.8 & $\begin{array}{c}(1.4) \\
\text { [ND] }\end{array}$ & 1.4 & $\begin{array}{l}(1.4) \\
{[1.6]}\end{array}$ & 1.8 & 1.8 & 1.6 \\
\hline $\begin{array}{c}\text { L. micdadei } \\
(\%+) \\
{[\%+]}\end{array}$ & $\begin{array}{l}33 \% \\
(2 / 6)\end{array}$ & $\begin{array}{c}(0 \%: 0 / 3) \\
{[66 \%: 2 / 3]}\end{array}$ & $\begin{array}{l}67 \% \\
(2 / 3)\end{array}$ & $\begin{array}{l}(16 \%: 1 / 6) \\
{[0 \%: 0 / 6]}\end{array}$ & $\begin{array}{l}67 \% \\
(2 / 3)\end{array}$ & $\begin{array}{c}0 \% \\
(0 / 6)\end{array}$ & $\begin{array}{l}17 \% \\
(1 / 6)\end{array}$ \\
\hline $\begin{array}{c}\text { L. micdadei } \\
\text { Geomean (Log } \\
\left.{ }_{10} \mathrm{GC} / 100 \mathrm{~mL}\right)\end{array}$ & 2.4 & $\begin{array}{c}\left(\mathrm{ND}^{\mathrm{a}}\right) \\
{[2.5]}\end{array}$ & 1.6 & $\begin{array}{c}(1.1) \\
{\left[\mathrm{ND}^{\mathrm{a}}\right]}\end{array}$ & 1.6 & $\mathrm{ND}^{\mathrm{a}}$ & 1.5 \\
\hline $\begin{array}{l}\text { L. bozemanii } \\
\qquad \%+) \\
{[\%+]}\end{array}$ & $\begin{array}{l}100 \% \\
(6 / 6)\end{array}$ & $\begin{array}{c}(0 \%: 0 / 3) \\
{[33 \%: 1 / 3]}\end{array}$ & $\begin{array}{l}100 \% \\
(3 / 3)\end{array}$ & $\begin{array}{l}(16 \%: 1 / 6) \\
{[16 \%: 1 / 6]}\end{array}$ & $\begin{array}{c}0 \% \\
(0 / 3)\end{array}$ & $\begin{array}{l}100 \% \\
(6 / 6)\end{array}$ & $\begin{array}{l}67 \% \\
(4 / 6)\end{array}$ \\
\hline
\end{tabular}


Table 1. Cont.

\begin{tabular}{|c|c|c|c|c|c|c|c|}
\hline $\begin{array}{l}\text { Legionella } \\
\text { Species }{ }^{b}\end{array}$ & $\mathrm{CT}(n=6)$ & $\begin{array}{l}\text { ERC Taps } \\
\text { (Cold } n=3 \text { ) } \\
{[\text { Hot } n=3]}\end{array}$ & ERC_IN $(n=3)$ & $\begin{array}{c}\text { Fa_Taps } \\
\text { (Cold } n=6) \\
{[\text { Hot } n=6]}\end{array}$ & $\begin{array}{l}\text { Fa_IN } \\
(n=3)\end{array}$ & Res_EF $(n=6)$ & Res_In $(n=6)$ \\
\hline $\begin{array}{c}\text { L. bozemanii } \\
\text { Geomean (Log } \\
\left.{ }_{10} \mathrm{GC} / 100 \mathrm{~mL}\right)\end{array}$ & 2.9 & $\begin{array}{c}\left(\mathrm{ND}^{\mathrm{a}}\right) \\
{[1.8]}\end{array}$ & 1.6 & $\begin{array}{l}(1.4) \\
{[1.8]}\end{array}$ & $\mathrm{ND}^{\mathrm{a}}$ & 1.7 & 1.5 \\
\hline $\begin{array}{c}\text { L. longbeachae } \\
(\%+) \\
{[\%+]}\end{array}$ & $\begin{array}{l}50 \% \\
(3 / 6)\end{array}$ & $\begin{array}{l}(0 \%: 0 / 3) \\
{[33 \%: 1 / 3]}\end{array}$ & $\begin{array}{l}100 \% \\
(3 / 3)\end{array}$ & $\begin{array}{l}(66 \%: 4 / 6) \\
{[50 \%: 3 / 6]}\end{array}$ & $\begin{array}{r}33 \% \\
(1 / 3)\end{array}$ & $\begin{array}{c}0 \% \\
(0 / 6)\end{array}$ & $\begin{array}{c}0 \% \\
(0 / 6)\end{array}$ \\
\hline $\begin{array}{l}\text { L. longbeachae } \\
\text { Geomean (Log } \\
\left.{ }_{10} \mathrm{GC} / 100 \mathrm{~mL}\right)\end{array}$ & 1.5 & $\begin{array}{c}\left(\mathrm{ND}^{\mathrm{a}}\right) \\
{[1.7]}\end{array}$ & 1.4 & $\begin{array}{l}(1.2) \\
{[1.6]}\end{array}$ & 1.5 & $\mathrm{ND}^{\mathrm{a}}$ & $\mathrm{ND}^{\mathrm{a}}$ \\
\hline $\begin{array}{c}\text { L. anisa } \\
(\%+) \\
{[\%+]}\end{array}$ & $\begin{array}{r}67 \% \\
(4 / 6)\end{array}$ & $\begin{array}{l}(0 \%: 0 / 3) \\
{[0 \%: 0 / 3]}\end{array}$ & $\begin{array}{c}0 \% \\
(0 / 3)\end{array}$ & $\begin{array}{l}(16 \%: 1 / 6) \\
{[66 \%: 4 / 6]}\end{array}$ & $\begin{array}{c}0 \% \\
(0 / 3)\end{array}$ & $\begin{array}{c}0 \% \\
(0 / 6)\end{array}$ & $\begin{array}{c}0 \% \\
(0 / 6)\end{array}$ \\
\hline $\begin{array}{c}\text { L.anisa } \\
\text { Geomean (Log } \\
\text { 10GC/100 mL) }\end{array}$ & 2.1 & $\begin{array}{l}\left(\mathrm{ND}^{\mathrm{a}}\right) \\
{\left[\mathrm{ND}^{\mathrm{a}}\right]}\end{array}$ & $\mathrm{ND}^{\mathrm{a}}$ & $\begin{array}{l}(1.1) \\
{[1.6]}\end{array}$ & $\mathrm{ND}^{\mathrm{a}}$ & $\mathrm{ND}^{\mathrm{a}}$ & $\mathrm{ND}^{\mathrm{a}}$ \\
\hline
\end{tabular}

a ND: No Detect; Detection limit is $1.3 \log _{10} \mathrm{GC} / 100 \mathrm{~mL}$. ${ }^{\mathrm{b}}$ The building samples were composites; thus, the Legionella concentrations represent composite concentration and not individual tap concentration.

Out of 42 samples, 16\% (7/42) of them only contained L. pneumophila and another $14 \%(6 / 42)$ of the samples contained only one of the five Legionella species (Supplementary Information Table S2). The co-occurrence of L. pneumophila with other Legionella species is considered in greater detail in the Supplemental Information Table S2. Table 2 presents the percentages of co-contamination with multiple Legionella species.

Table 2. Number of samples with no-detects, single and multiple Legionella species.

\begin{tabular}{cc}
\hline Number of Different Legionella spp. & $\begin{array}{c}\text { Percent Positive } \%+ \\
\text { (Sample Positive/Total Number of Samples) }\end{array}$ \\
\hline 0 & 7 \\
$(3 / 42)$ \\
3
\end{tabular}

3.2. Detection of $23 S$ rRNA and Five Legionella Species from Groundwater Source to the Taps in the Buildings, to the Cooling Towers

The concentration of total Legionella spp. (23S rRNA) in the influent pipe of the reservoir (RES_IN) was $3.1 \log _{10} \mathrm{GC} / 100 \mathrm{~mL}$ and in the effluent pipe of the reservoir (RES_EF) the concentration decreased to $2.7 \log _{10} \mathrm{GC} / 100 \mathrm{~mL}$. The $\log _{10} \mathrm{GC} / 100 \mathrm{~mL}$ of total Legionella spp. (23S rRNA) of building Fa [in the influent water pipe, the cold- and hot-water taps] was about the same as the reservoir effluent, all four sampling locations ranged from 2.2 to $2.7 \log _{10} \mathrm{GC} / 100 \mathrm{~mL}$ (Figure 1). It is interesting to note that the similar concentrations of total Legionella spp. between building $\mathrm{Fa}$ and the reservoir may be due to the fact this building is closest to the reservoir (water age is $9.2 \mathrm{~h}$ ) relative to the building ERC. Building ERC had a water age of $20.8 \mathrm{~h}$, and the concentration of total Legionella 
spp. significantly increased (Figure 1). Total Legionella spp. (23S rRNA) concentrations in building ERC detected in the influent water pipe, hot- and cold-water taps were 4.0, 4.3 and $4.5 \log _{10} \mathrm{GC} / 100 \mathrm{~mL}$, respectively (Figure 1). The cooling towers (4.5 $\log _{10} \mathrm{GC} / 100$ $\mathrm{mL}$ ) had similar concentrations of total Legionella spp. (23S rRNA) compared to building ERC, once again significantly $(p=0.0003)$ higher than the reservoir effluent $\left(2.7 \log _{10}\right.$ $\mathrm{GC} / 100 \mathrm{~mL}$ ) (Figure 1). These data suggests that both the water age and more importantly building water management contributes to the growth of Legionella species.

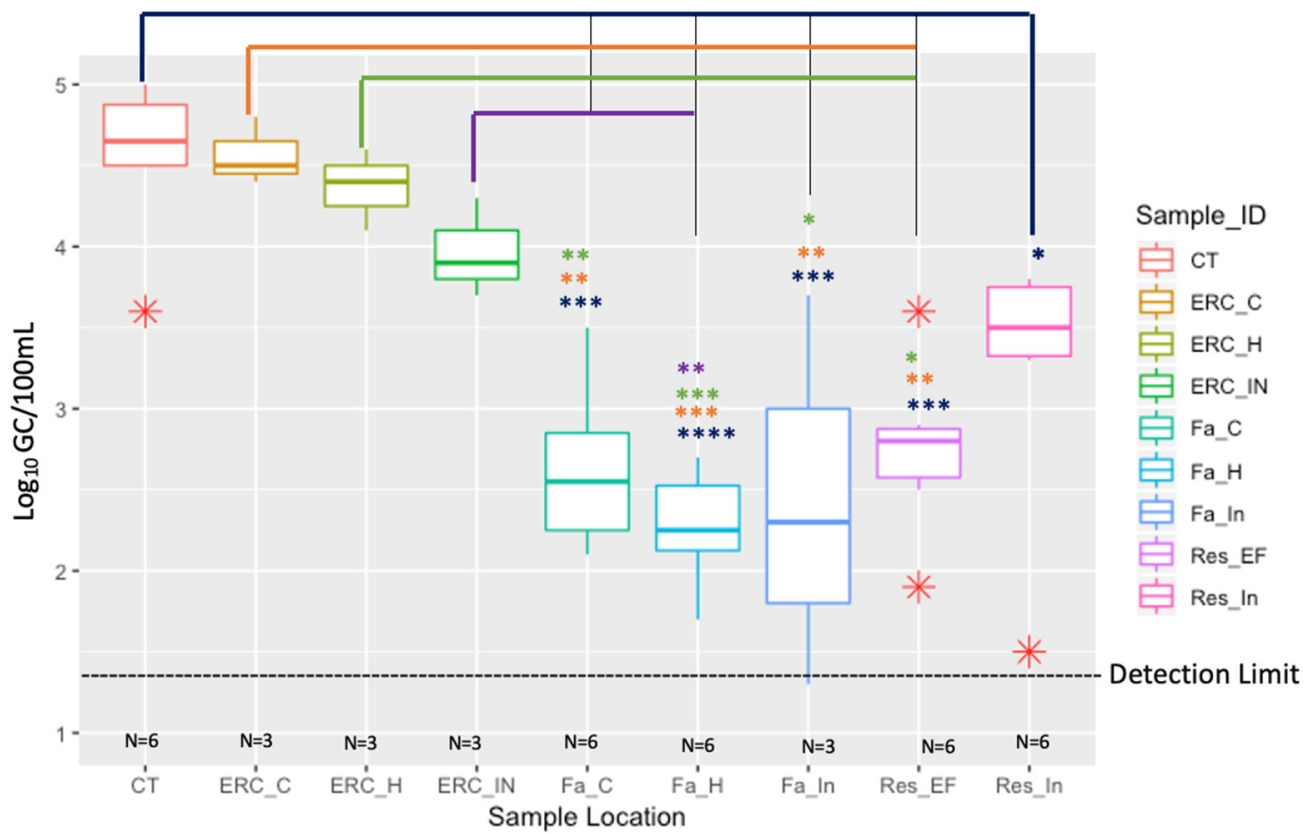

Figure 1. Comparison of Legionella spp. (23S rRNA) in the reservoir (RES_IN and RES_EF), buildings: Fa and ERC, and the Cooling Towers (CT). The water age (h) in Res_In (4.5 h), Res_EF (3.4 h), Fa (9.2 h), ERC (20.8 h), and CT (23.2 h). Description names are as follows: Res_In: Reservoir Influent; Res_Ef: Reservior Effluent; Fa_In: Fa Influent; Fa_H: Fa Hot-water tap; Fa_C: Fa Cold-water tap; ERC_In: ERC Influent; ERC_H: ERC Hot-water tap; ERC_C: ERC Cold-water tap; CT: Cooling Towers. The median of each measure is indicated by the thick colorful bar in each respective box; the first and third quartiles are represented by the bottom and top of the box, respectively; the red asterisks $\left.{ }^{*}\right)$ show depicts the outliers within three sample types. The different asterisk $(*, * *, * *, * * *)$ colors represent the significant difference between sampling location and is as follows: blue: CT; orange: ERC_C; green: ERC_H; purple: ERC_IN. Detection limit was $1.3 \log _{10}$ GC/100 mL.

Overall, the geometric mean concentrations of total Legionella spp. (23S rRNA) in the cooling towers and in the ERC building (both influent, hot- and cold-water taps) were statistically higher than what was found in the influent and effluent of the reservoir, influent, cold- and hot-water taps of building Fa (Figure 1). The $p$ values showing the most significance were the cooling towers compare to the reservoir effluent and building Fa. This significant pattern was also true for the ERC building compared to building Fa and the reservoir (Figure 1). The detailed description of the ANOVA results are as follows: CT vs. Res_In, (0.0156); CT vs. Res_EF (0.0003); CT vs. Fa_In (0.0006); CT Vs Fa_H (<0.0001); CT vs. Fa_C (0.0001); ERC_C vs. Res_EF (0.0043); ERC_C vs. Fa_In (0.0036); ERC_C vs. Fa_H (0.0002); ERC_C vs. Fa_C (0.0020); ERC_H vs. Res_EF (0.0152); ERC_H vs. Fa_In (0.0107); ERC_H vs. Fa_H (0.0007); ERC_H vs. Fa_C (0.0074); ERC_In vs. Fa_H (0.0091) Table 3. The five Legionella species concentration data did not show a clear trend relative to water age; thus, it was decided to present the data in a table format (Table 1). 
Table 3. Detailed description of the ANOVA results for the significant pairs shown in Figure 1.

\begin{tabular}{cccc}
\hline No. of Pairs & Pairs & $p$-Value & Remarks \\
\hline 1 & CT vs. RES_IN & 0.0156 & Significant \\
\hline 2 & CT vs. RES_EF & 0.0003 & Highly significant \\
\hline 3 & CT vs. Fa_IN & 0.0006 & Highly significant \\
\hline 4 & CT vs. Fa_H & $<0.0001$ & Highly significant \\
\hline 5 & CT vs. Fa_C & 0.0001 & Highly significant \\
\hline 6 & ERC_C vs. RES_EF & 0.0043 & Very significant \\
\hline 7 & ERC_vs. Fa_IN & 0.0036 & Very significant \\
\hline 8 & ERC vs_Fa_H & 0.0002 & Highly significant \\
\hline 9 & ERC_C vs Fa_C & 0.0020 & Very significant \\
\hline 10 & ERC_H vs. RES_EF & 0.0152 & Significant \\
\hline 11 & ERC_H vs. Fa_IN & 0.0107 & Significant \\
\hline 12 & ERC_H vs. Fa_H & 0.0007 & Highly Significant \\
\hline 13 & ERC_H vs. Fa_C & 0.0074 & Significant \\
\hline 14 & ERC_IN vs. Fa_H & 0.0091 & Significant \\
\hline
\end{tabular}

Specific pathogenic Legionella species were detected in the reservoir (influent and effluent), the buildings, and the cooling towers. The geometric means with non-detects used at the detection limit are presented in the paragraphs below. Legionella bozemanii, L. micdadei, and L. pneumophila were detected in the influent of the reservoir (Res_IN) at geometric mean concentrations of 1.5, 1.5, $1.6 \log _{10} \mathrm{GC} / 100 \mathrm{~mL}$, respectively. Legionella pneumophila and L. bozemanii were detected in the effluent of the reservoir at geometric mean concentrations of 1.8 and $1.7 \log _{10} \mathrm{GC} / 100 \mathrm{~mL}$. Legionella longbeachae, L. pneumophila, and L. micdadei were detected in the influent water pipes of buildings $\mathrm{Fa}$ at geometric mean concentration of $1.5,1.8$, and $1.6 \log _{10} \mathrm{GC} / 100 \mathrm{~mL}$, respectively. All three species concentrations decreased at the taps in building $\mathrm{Fa}$ (Table 1). Legionella micdadei, L. bozemanii, L. pneumophila, and L. longbeachae were detected in the influent water pipes of the ERC building at geometric mean concentrations of 1.6, 1.6, 1.4, and $1.4 \log _{10} \mathrm{GC} / 100 \mathrm{~mL}$, respectively (Table 1). All four species concentrations either stabilized (same concentration) or decreased at the taps in building ERC (Table 1).

Most of the pathogenic Legionella species were much more prevalent and found in cooling towers at much higher concentrations. In the cooling towers, L. bozemanii had the highest concentration at $3.0 \log _{10} \mathrm{GC} / 100 \mathrm{~mL}$ followed by L. pneumophila (2.8), L. micdadei (2.4), L. anisa (2.1), and L. longbeachae at $1.5 \log _{10}$ GC/100 mL (Tables 1 and 3).

\subsection{Water Quality Parameters}

The water quality characteristics of the reservoir, the buildings, and the cooling towers are presented in Table 4. 
Table 4. Water quality parameters of the reservoir (influent and effluent), the influent, hot- and cold-water (all three sample types were collected on the same day, but replicates were collected on different days) in buildings (Fa and ERC), and the CT. Sample collection dates are as follows: reservoir (influent and effluent), 15, 23 and 29 July and 6, 13 and 20 August; influent, hot-, and cold-water in building Fa, 12 August and 3, 16 September; influent, hot-, and cold-water in building ERC, 19 August, and 9, 23 September; CT, 25, 31 July and 7, 14 and 21 August; two cooling tower water samples were collected on the 21 st.

\begin{tabular}{|c|c|c|c|c|c|c|c|c|}
\hline $\begin{array}{l}\text { Temperature } \\
\left({ }^{\circ} \mathrm{C}\right)\end{array}$ & $\begin{array}{c}\text { Total } \\
\text { Chlorine } \\
\text { (mg/L) }\end{array}$ & $\begin{array}{c}\text { Free } \\
\text { Chlorine } \\
\text { (mg/L) }\end{array}$ & $\begin{array}{l}\text { Turbidity } \\
\text { (NTU) }\end{array}$ & $\mathrm{pH}$ & $\begin{array}{l}\text { Conductivity } \\
(\mathrm{mS})\end{array}$ & $\begin{array}{c}\text { HPC } \\
(\mathrm{CFU} / 100 \mathrm{~mL})\end{array}$ & $\begin{array}{l}\text { Total Coliforms } \\
\text { (MPN/100 mL) }\end{array}$ & $\begin{array}{c}\text { E. coli } \\
\text { (MPN/100 mL) }\end{array}$ \\
\hline \multicolumn{9}{|c|}{ Reservoir Influent $(n=6)$} \\
\hline 12.1 & 0 & 0 & 4.1 & 7.2 & 851 & $3.52 \times 10^{1}$ & $<1$ & $<1$ \\
\hline \multicolumn{9}{|c|}{ Reservoir Effluent $(n=6)$} \\
\hline 11.9 & 0.64 & 0.33 & 3.85 & 7.2 & 855 & $2.10 \times 10^{0}$ & $<1$ & $<1$ \\
\hline \multicolumn{9}{|c|}{ Building Fa Influent $(n=3)$} \\
\hline 26.8 & 0.41 & 0.35 & 8.4 & 7.3 & 897 & $8.57 \times 10^{4}$ & $<1$ & $<1$ \\
\hline \multicolumn{9}{|c|}{$\begin{array}{l}\text { Building Fa } 1 \text { st Floor Cold; } n=3 \\
\text { (Hot Taps; } n=3 \text { ) }\end{array}$} \\
\hline $\begin{array}{c}26.7 \\
(28.6)\end{array}$ & $\begin{array}{c}0.16 \\
(0.04)\end{array}$ & $\begin{array}{c}0.14 \\
(0.02)\end{array}$ & $\begin{array}{c}3.06 \\
(0.53)\end{array}$ & $\begin{array}{c}7.2 \\
(7.1)\end{array}$ & $\begin{array}{c}867 \\
(815)\end{array}$ & $\begin{array}{l}1.02 \times 10^{4} \\
\left(7.3 \times 10^{3}\right)\end{array}$ & $\begin{array}{c}<1 \\
(<1)\end{array}$ & $\begin{array}{l}<1 \\
(<1)\end{array}$ \\
\hline \multicolumn{9}{|c|}{$\begin{array}{l}\text { Building Fa 2nd Floor Cold; } n=3 \\
\text { (Hot Taps; } n=3 \text { ) }\end{array}$} \\
\hline $\begin{array}{c}26.8 \\
(28.8)\end{array}$ & $\begin{array}{c}0.05 \\
(0.02)\end{array}$ & $\begin{array}{l}0.03 \\
(0)\end{array}$ & $\begin{array}{c}3.37 \\
(0.67)\end{array}$ & $\begin{array}{l}7.0 \\
(6.9)\end{array}$ & $\begin{array}{c}856 \\
(822)\end{array}$ & $\begin{array}{l}2.00 \times 10^{4} \\
\left(3.15 \times 10^{3}\right)\end{array}$ & $\begin{array}{l}<1 \\
(<1)\end{array}$ & $\begin{array}{l}<1 \\
(<1)\end{array}$ \\
\hline \multicolumn{9}{|c|}{ Building ERC Influent $(n=3)$} \\
\hline 31.5 & 0.31 & 0.20 & 12.5 & 7.4 & 883 & $4.32 \times 10^{5}$ & $<1$ & $<1$ \\
\hline \multicolumn{9}{|c|}{$\begin{array}{l}\text { Building ERC } 1 \text { st Floor Cold }(n=3) \\
\text { (Hot Taps; } n=3)\end{array}$} \\
\hline $\begin{array}{c}23.5 \\
(24.5)\end{array}$ & $\begin{array}{c}0.09 \\
(0.04)\end{array}$ & $\begin{array}{l}0.03 \\
(0)\end{array}$ & $\begin{array}{c}5.97 \\
(6.27)\end{array}$ & $\begin{array}{c}7.6 \\
(7.5)\end{array}$ & $\begin{array}{c}866 \\
(847)\end{array}$ & $\begin{array}{c}4.38 \times 10^{5} \\
\left(6.80 \times 10^{5}\right)\end{array}$ & $\begin{array}{l}<1 \\
(<1)\end{array}$ & $\begin{array}{l}<1 \\
(<1)\end{array}$ \\
\hline \multicolumn{9}{|c|}{ CT $(n=6)$} \\
\hline 25.3 & 0.49 & 0.08 & 1.94 & 8.2 & 2564 & $2.35 \times 10^{7}$ & 666.6 & 17.3 \\
\hline
\end{tabular}

Water temperature in the reservoir (influent and effluent) ranged from 11.6 to $12.3^{\circ} \mathrm{C}$; the free chlorine residual in the reservoir influent was $0 \mathrm{mg} / \mathrm{L}$, and in the reservoir effluent, the average value was $0.64 \mathrm{mg} / \mathrm{L}$ (water quality averages shown in Table 4). The conductivity ranged from 620 to $1032 \mu \mathrm{S} / \mathrm{cm}$ and the turbidity ranged from 1.08 to $9.55 \mathrm{NTU}$; the $\mathrm{pH}$ ranged from 7.1 to 7.4. The HPCs in the reservoir influent ranged from $1.50 \times 10^{1}$ to $7.80 \times 10^{1} \mathrm{CFU} / 100 \mathrm{~mL}$, and decreased in the reservoir effluent, and ranged from 1.0 to 6.0 CFU/100 mL. The water quality parameters between the building influents of $\mathrm{Fa}$ and ERC were statistically different from each other. The water temperatures, turbidity, $\mathrm{pH}$, and HPC (cold and hot separate samples) on both floors in building Fa were statistically different from building ERC (Table 4). Overall, the water temperature at the effluent of the reservoir was $11.9^{\circ} \mathrm{C}$ but increased at both $\mathrm{Fa}\left(26.8^{\circ} \mathrm{C}\right)$ and ERC $\left(31.5^{\circ} \mathrm{C}\right)$ building influent pipe-suggesting that water age is a factor in the water quality parameters as it relates to the pipe distance within each building incoming water and not at the cold- and hot-water taps. Some of the results in Table 4 are also available in a previously published paper [28]. Table 4 is adapted with permission from ref. [28]. (2021, Alshae, R. Logan-Jackson).

A higher variance of all the water quality parameters was noted in the cooling towers (Table 4). Interestingly, total coliforms and E. coli were also seen in the cooling towers at 17.3 and $666.6 \mathrm{MPN} / 100 \mathrm{~mL}$, respectively (Table 4). The cooling towers receive water from the effluent of the reservoir; thus, the contamination of E. coli may be due to birds-this hypothesize was thought of because the cooling water is directly exposed to the atmosphere. 
Biocides used in the cooling tower are in rotation with different chemicals: glutaraldehyde, a mixture of polyethylene glycol and 2,2-Dibromo-3-nitrilopropionamide, as well as sodium hypochlorite (chlorine was used separately from the organic biocides). However, these different types of substances/mixtures did not always control fecal indicator and HPC bacteria but may be decreasing cultivatable Legionella (as the utility responsible for the cooling towers does monitor L. pneumophila with culture techniques by a state laboratory).

\section{Discussion}

While there have been several studies that revealed the differences of total Legionella spp. comparing various exposure sites [20,29-33], only a couple of studies have examined how the hydraulic retention time (water age) influenced Legionella spp. in building water systems [34,35]. Nguyen et al., 2012 [34] compared four tap water sites in an undisclosed location where one site lacked a toilet (thus water use was decreased) and found no difference in Legionella species detected. Rhoads et al., 2016 [35] surveyed four buildings, three buildings were green compared to a conventional house. The hydraulic retention time for each house/ building was $~ 1,2.7,8$ and 30-180 days; quantitative PCR (qPCR) data showed that Legionella spp. (23S rRNA) were mostly detected in the green buildings (water ages were 2.7 and 30-180 days) relative to the conventional buildings (water age of 1 and day/s) [35].

Low water usage can increase water age as defined by the length of time the water sits in the premise plumbing; this can be influenced by low number of occupants in a portion of the building, water conservation features, or even the low flow features. However, dayto-day water stagnation in complex water systems is a challenging parameter to measure. Nguyen et al. (2012) [34] and Rhoads et al. (2016) [35] determined water age by water usage patterns within premise plumbing systems. The study described herein evaluated the water age as it related to pipe mileage from the reservoir to the premise for buildings Fa and ERC, which are closest and furthest from the reservoir, respectively. By collecting $10 \mathrm{~L}$ samples the goal was to understand how water age contributes to the growth of Legionella throughout a building as opposed to an individual tap/s. Building design and operation contributes to water age at various taps throughout an entire building; thus, the authors believed that collecting $10 \mathrm{~L}$ composite samples in a building would help to compare the water ages of buildings that are structurally different to the water source and cooling towers. Building ERC had high levels of Legionella 23S rRNA despite high water use (five-year average: $738,533 \mathrm{~L} /$ month compared to FA five-year average of 173,993 L/month) due to use of a cooling tower, which was located on top of the premise-the higher water usage patterns did not impact the Legionella concentrations. Building Fa had a lower water usage pattern, and lacked a cooling tower, but had less hydraulic retention time in the distribution system (closest to the reservoir); thus, less time in the distribution system contributed to lower levels of Legionella spp. (23S rRNA) at every sampling location inside the building. These data suggests that the length of pipe and the distance from the water source influenced the premise water age and not the water usage patterns (which is influenced by occupants). The other water quality parameters including $\mathrm{pH}, \mathrm{HPC}$, turbidity, and temperature were also different between the two buildings, however these characteristics were not predictive in terms of the increase of Legionella observed at the taps. The regression analysis data suggested that the water age is driving the relationship between water quality parameters (HPCs, pH, temperature, and turbidity) and Legionella spp. (23S rRNA) and not the individual indicators (data not shown). However, this observation from the regression analysis will need to be further elucidated with a more extensive data set: such as increasing the total number of samples, sampling and analyzing the biofilm, and verifying the ddPCR results with DNA sequencing. Overcoming such limitations would increase this study significance. Nonetheless, the regression analysis further emphasizes that it is a building water issue - the building management and the distance from the water source influenced the premise water age which impacted the water quality in buildings Fa and ERC, causing these two buildings to be distinctly different 
Legionella species that are mostly associated with human disease are L. pneumophila, L. micdadei, L. bozemanii, L. longbeachae, and L. anisa [6]. In the U.S., there were approximately 7500 and 10,000 Legionnaires' Disease cases reported in 2017 and 2018, respectively [36]. The increasing trend of Legionnaires' Disease cases are primarily attributed to L. pneumophila [37] which is thought to account for $95 \%$ of the cases. However, L. anisa, L. micdadei, L. bozemanii, and L. longbeachae may pose as great a risk as L. pneumophila-or more than previously recognized [6]. In several studies L. anisa species appeared to be more prevalent in environmental water samples [38-40] at levels as high as $3.0 \times 10^{4} \mathrm{GC} / 100 \mathrm{~mL}$ [41]. Health Departments should consider Legionnaires' Disease from other Legionella species as these species are also found in building water systems and cooling towers [25,28,42-45]. As shown here Legionella pathogenic species are contributing to approximately 0.1 to $10 \%$ of the Legionella present at the taps and cooling towers and in some cases the concentrations of the specific Legionella species were high enough to be of some concern (L. bozemanii-3.0 $\log _{10}$ GC/100 mL). In large community-wide outbreaks of Legionnaires' Disease such as in Flint, Michigan [46,47] where multiples species could possibly be causing disease, only L. pneumophila is looked for and thus disease caused by other species would go underestimated.

In this study, the concentrations of the specific Legionella pathogenic species ranged from 1.1 to $3.0 \log _{10} \mathrm{GC} / 100 \mathrm{~mL}$ (geomean: $1.6 \log _{10} \mathrm{GC} / 100 \mathrm{~mL}$ ) at the exposure sites. Previous risk assessments suggest that the level which equates to approximately $10^{-4}$ annual goal for drinking water safety is around 5.0 $\log _{10} \mathrm{CFU} / \mathrm{L}\left(4.0 \mathrm{Log}_{10} \mathrm{CFU} / 100 \mathrm{~mL}\right)$ for faucets and 3.0 $\log _{10} \mathrm{CFU} / \mathrm{L}\left(2.0 \mathrm{Log}_{10} \mathrm{CFU} / 100 \mathrm{~mL}\right)$ for showers [48]. Thus, these concentrations at the exposure sites are near the level of the acceptable annual goal- assuming these other pathogenic species are $100 \%$ cultivable and have similar dose-response characteristics (for example, the number and expression of virulence genes) as L. pneumophila. This assumption is also based on the fact the concentrations presented herein would be similar throughout the year.

There are guidelines and regulations for the control of Legionella in cooling tower systems. For example, in the U.S., guidance is provided by ASHRAE 188 standard and American Industrial Hygiene Association [49,50], while some states (e.g., New York) have a mandatory monitoring scheme which is based on culturing Legionella that grows on a selective media [51]. The concentration of concern is equal to or greater than $10^{3} \mathrm{CFU} / \mathrm{mL}$ $\left(10^{5} \mathrm{CFU} / 100 \mathrm{~mL}\right)$ and this would require corrective action [50]. Legionella spp. (23S rRNA), and pathogenic species concentrations (listed above) were near the safety levels established in the AIHA guidelines [50]. While it understood that concentrations of Legionella by the culture method (CFU) cannot be directly compared to molecular methods (PCR), it is worth noting that Legionella spp. (23S rRNA), and pathogenic species concentrations were 4.5 and 3.0 $\log _{10} \mathrm{GC} / 100 \mathrm{~mL}$, respectively by ddPCR. Although, ddPCR could be evaluating non-infectious bacteria, it could also be enumerating bacteria inside its host cell [52].

Legionella species occurrence and concentration may be underestimated by utilizing a small grab sample $(0.25 \mathrm{~L}$ or $1 \mathrm{~L})$ and quantifying using culture techniques. It will be critical to understand whether these other Legionella disease relevant species at such concentrations (i.e., L. bozemanii $3.0 \mathrm{Log}_{10} \mathrm{GC} / 100 \mathrm{~mL}$ ) are also associated with risk- as the cooling towers are in the ideal temperature range $\left(25^{\circ} \mathrm{C}-45^{\circ} \mathrm{C}\right.$, [53]) for these species to proliferate. Thus, a rapid PCR monitoring scheme — using a $10 \mathrm{~L}$ composite sample—could result in improved strategies to control the amplification of disease relevant Legionella species (L. pneumophila, L. anisa, L. micdadei, L. bozemanii, and L. longbeachae) in taps and cooling towers to holistically understand the building water quality rather than individual taps. While this study revealed information about how the water age and building water quality impacted the occurrence and concentration of Legionella species, this study would benefit from a more extensive, year-long data set to achieve a higher significance. It is also important to note that the temperature data were not taken from the water heater set point or the recirculation loops in the two buildings; thus, this study could also benefit from a 
systematic understanding on how different the water quality is as it relates to the cold- and hot-water systems.

\section{Conclusions}

Overall, water age, as defined in this study, is only one of multiple factors that plays a role in the Legionella spp. colonization of buildings and cooling towers, as seen in the ERC building. Water age is an important factor that contribute to the occurrence and the abundance of Legionella species but is not the most important factor. For example, water management in the building is the most critical factor that contributes to the growth of Legionella species. Critical building factors such as infrequent water usage, water quality parameters, or the plumbing design of a building may create growth and niches for Legionella. Aside from building management, water quality in buildings, especially the buildings that' are furthest away from water treatment may be challenged, thus, further information by water utilities on hydraulic retention times and disinfection boosters may be needed. Concentrations increasing above $100 \mathrm{GC} / \mathrm{L}$ could be targeted for remediation. Distribution and premise plumbing systems remain a source of risk from several pathogenic Legionella species. It is likely that disease associated with L. micdadei, L. bozemanii, L. longbeachae, and perhaps L. anisa are underestimated and more information on culturability and viability are warranted.

Since 2009, L. pneumophila has been on the United States Environmental Protection Agency (USEPA) Candidate Contaminant List (CCL); thus, there are reasons to believe that there should be federal regulations for monitoring and controlling this primary waterrelated bacterium. Ultimately, a routine monitoring scheme would help to target better management approaches to decrease the morbidity and mortality rate of Legionnaires' Disease-caused by L. pneumophila, and other species from common exposure sites (hotwater taps and especially cooling towers) where conditions are favorable for their proliferation, and where Legionella-containing aerosols are generated.

Supplementary Materials: The following are available online at https: / www.mdpi.com/article/ 10.3390 / microorganisms10010081/s1, Table S1. General and specific Legionella primers and probes. $23 \mathrm{~S}$ pan-Legionella is conserved by all species of Legionella; but the probes were uniquely designed to specifically identify each species: L. micdadei, L. anisa, L.bozemanii, and L. longbeachae. ddPCR Information. Table S2. Raw data of Five Disease Relevant Legionella species. References [54,55] are cited in the Supplementary Materials.

Author Contributions: Conceptualization, A.R.L.-J. and J.B.R.; methodology, A.R.L.-J. analysis, A.R.L.-J.: investigation, A.R.L.-J.: resources, J.B.R.; writing-original draft preparation, A.R.L.-J.: writing-review and editing, A.R.L.-J. and J.B.R.; visualization, A.R.L.-J.: supervision, J.B.R. All authors have read and agreed to the published version of the manuscript.

Funding: This work was supported by the U.S. EPA Grant No. (FAIN): 83689001 and U.S. EPA agreement number R836890. The contents of this publication are solely the responsibility of the authors and do not represent the official views of the EPA.

Institutional Review Board Statement: Not applicable.

Informed Consent Statement: Not applicable.

Acknowledgments: A.L.-J. thanks Matthew Flood, Parker Kelly, and Rebecca Ives for their assistance on sampling. A.L.-J. thanks the Infrastructure Plant Facility Staff at MSU for their assistance sampling the buildings and the cooling towers.

Conflicts of Interest: The authors declare no conflict of interest. 


\section{References}

1. Fraser, D.W.; Tsai, T.R.; Orenstein, W.; Parkin, W.E.; Beecham, H.J.; Sharrar, R.G.; Harris, J.; Mallison, G.F.; Martin, S.M.; McDade, J.E.; et al. Legionnaires' disease: Description of an epidemic of pneumonia. N. Engl. J. Med. 1977, 297, 1189-1197. [CrossRef] [PubMed]

2. Brenner, D.J.; Steigerwalt, A.G.; McDade, J.E. Classification of the Legionnaires' disease bacterium: Legionella pneumophila, genus novum, species nova, of the family Legionellaceae, familia nova. Ann. Intern. Med. 1979, 90, 656-658. [CrossRef] [PubMed]

3. Zeng, L.Z.; Liao, H.Y.; Luo, L.Z.; He, S.S.; Qin, T.; Zhou, H.J.; Li, H.X.; Chen, D.L.; Chen, J.P. An Investigation on the Molecular Characteristics and Intracellular Growth Ability among Environmental and Clinical Isolates of Legionella pneumophila in Sichuan Province, China. Biomed. Environ. Sci. BES 2019, 32, 520-530. [CrossRef]

4. Brady, M.F.; Sundareshan, V. Legionnaires' Disease (Legionella Infection). In StatPearls; StatPearls Publishing: Treasure Island, FL, USA, 2019. Available online: http:/ / www.ncbi.nlm.nih.gov/books/nbk430807/ (accessed on 25 March 2020).

5. Waldron, P.R.; Martin, B.A.; Ho, D.Y. Mistaken identity: Legionella micdadei appearing as acid fast bacilli on lung biopsy of a hematopoietic stem cell transplant patient. Transpl. Infect. Dis. 2015, 17, 89-93. [CrossRef]

6. Muder, R.R.; Victor, L.Y. Infection Due to Legionella Species Other Than L. pneumophila. Clin. Infect. Dis. 2002, 35, 990-998. [CrossRef]

7. Sanchez, M.C.; Sebti, R.; Hassoun, P.; Mannion, C.; Goy, A.H.; Feldman, T.; Mato, A.; Hong, T. Osteomyelitis of the patella caused by Legionella anisa. J. Clin. Microbiol. 2013, 51, 2791-2793. [CrossRef]

8. Lachant, D.; Prasad, P. Legionella micdadei: A Forgotten Etiology of Growing Cavitary Nodules: A Case Report and Literature Review. Case Rep. Pulmonol. 2015, 2015, 535012. [CrossRef] [PubMed]

9. Miller, M.L.; Hayden, R.; Gaur, A. Legionella Bozemanii Pulmonary Abscess in a Pediatric Allogeneic Stem Cell Transplant Recipient. Pediatric Infect. Dis. J. 2007, 26, 760-762. [CrossRef]

10. Centers for Disease Control and Prevention. Legionella (Legionnaires' Disease and Pontiac Fever). Surveillance Report 2016-2017. Available online: https:/ / www.cdc.gov/legionella/health-depts/surv-reporting/2016-17-report-tables/index.html\#figure1 (accessed on 28 October 2020).

11. Brunkard, J.M.; Ailes, E.; Roberts, V.A.; Hill, V.; Hilborn, E.D.; Craun, G.F.; Rajasingham, A.; Kahler, A.; Garrison, L.; Hicks, L.; et al. Surveillance for waterborne disease outbreaks associated with drinking water-United States, 2007-2008. Morb. Mortal. Wkly. Rep. Surveill. Summ. 2011, 60, 38-68.

12. United States Geological Survey. Summary of Estimated Water Use in the United States in 2015. Available online: https: / / pubs.usgs.gov/fs/2018/3035/fs20183035.pdf (accessed on 27 May 2020).

13. Department of Environmental Quality. Fact Sheet. Groundwater Statistics. Available online: https://www.michigan.gov/ documents/deq/deq-wd-gws-wcu-groundwaterstatistics_270606_7.pdf (accessed on 2 April 2020).

14. Brooks, T.; Osicki, R.; Springthorpe, V.; Sattar, S.; Filion, L.; Abrial, D.; Riffard, S. Detection and identification of Legionella species from groundwaters. J. Toxicol. Environ. Health Part A 2004, 67, 1845-1859. [CrossRef]

15. De Giglio, O.; Napoli, C.; Apollonio, F.; Brigida, S.; Marzella, A.; Diella, G.; Calia, C.; Scrascia, M.; Pacifico, C.; Pazzani, C.; et al. Occurrence of Legionella in groundwater used for sprinkler irrigation in Southern Italy. Environ. Res. 2019, 170, $215-221$. [CrossRef] [PubMed]

16. Valcina, O.; Pūle, D.; Mališevs, A.; Trofimova, J.; Makarova, S.; Konvisers, G.; Bērzin̄̌s, A.; Krūmina, A. Co-Occurrence of Free-Living Amoeba and Legionella in Drinking Water Supply Systems. Medicina 2019, 55, 492. [CrossRef] [PubMed]

17. Mapili, K.; Pieper, K.J.; Dai, D.; Pruden, A.; Edwards, M.A.; Tang, M.; Rhoads, W.J. Legionella pneumophila occurrence in drinking water supplied by private wells. Lett. Appl. Microbiol. 2020, 70, 232-240. [CrossRef]

18. Johnson, C.D.; Nandi, A.; Joyner, T.A.; Luffman, I. Iron and Manganese in Groundwater: Using Kriging and GIS to Locate High Concentrations in Buncombe County, North Carolina. Ground Water 2018, 56, 87-95. [CrossRef] [PubMed]

19. Cianciotto, N.P. An update on iron acquisition by Legionella pneumophila: New pathways for siderophore uptake and ferric iron reduction. Future Microbiol. 2015, 10, 841-851. [CrossRef]

20. Donohue, M.J.; O'Connell, K.; Vesper, S.J.; Mistry, J.H.; King, D.; Kostich, M.; Pfaller, S. Widespread Molecular Detection of Legionella pneumophila Serogroup 1 in Cold Water Taps across the United States. Environ. Sci. Technol. 2014, 48, 3145-3152. [CrossRef]

21. Llewellyn, A.C.; Lucas, C.E.; Roberts, S.E.; Brown, E.W.; Nayak, B.S.; Raphael, B.H.; Winchell, J.M. Distribution of Legionella and bacterial community composition among regionally diverse US cooling towers. PLoS ONE 2017, 12, e0189937. [CrossRef]

22. Prussin, A.J.; Schwake, D.O.; Marr, L.C. Ten Questions Concerning the Aerosolization and Transmission of Legionella in the Built Environment. Build. Environ. 2017, 123, 684-695. [CrossRef]

23. Dilger, T.; Melzl, H.; Gessner, A. Legionella contamination in warm water systems: A species-level survey. Int. J. Hyg. Environ. Health 2017, 221, 199-210. [CrossRef]

24. Richards, C.L.; Broadaway, S.C.; Eggers, M.J.; Doyle, J.; Pyle, B.H.; Camper, A.K.; Ford, T.E. Detection of Pathogenic and Non-pathogenic Bacteria in Drinking Water and Associated Biofilms on the Crow Reservation, Montana, USA. Microb. Ecol. 2018, 76, 52-63. [CrossRef]

25. Lesnik, R.; Brettar, I.; Höfle, M.G. Legionella species diversity and dynamics from surface reservoir to tap water: From cold adaptation to thermophily. ISME J. 2016, 10, 1064-1080. [CrossRef] 
26. Tsao, H.-F.; Scheikl, U.; Herbold, C.; Indra, A.; Walochnik, J.; Horn, M. The cooling tower water microbiota: Seasonal dynamics and co-occurrence of bacterial and protist phylotypes. Water Res. 2019, 159, 464-479. [CrossRef] [PubMed]

27. Pereira, R.P.A.; Peplies, J.; Brettar, I.; Höfle, M.G. Development of a genus-specific next generation sequencing approach for sensitive and quantitative determination of the Legionella microbiome in freshwater systems. BMC Microbiol. 2017, 17, 79. [CrossRef] [PubMed]

28. Logan-Jackson, A.; Rose, J.B. Cooccurrence of Five Pathogenic Legionella spp. And Two Free-Living Amoebae Species in a Complete Drinking Water System and Cooling Towers. Pathogens 2021, 10, 1407. [CrossRef] [PubMed]

29. Lu, J.; Buse, H.; Struewing, I.; Zhao, A.; Lytle, D.; Ashbolt, N. Annual variations and effects of temperature on Legionella spp. And other potential opportunistic pathogens in a bathroom. Environ. Sci. Pollut. Res. 2017, 24, 2326-2336. [CrossRef]

30. Totaro, M.; Valentini, P.; Costa, A.L.; Frendo, L.; Cappello, A.; Casini, B.; Miccoli, M.; Privitera, G.; Baggiani, A. Presence of Legionella spp. in Hot Water Networks of Different Italian Residential Buildings: A Three-Year Survey. Int. J. Environ. Res. Public Health 2017, 14, 1296. [CrossRef] [PubMed]

31. Hull, N.M.; Holinger, E.P.; Ross, K.A.; Robertson, C.E.; Harris, J.K.; Stevens, M.J.; Pace, N.R. Longitudinal and Source-to-Tap New Orleans, LA, USA. Drinking Water Microbiology. Environ. Sci. Technol. 2017, 51, 4220-4229. [CrossRef]

32. Li, L.; Qin, T.; Li, Y.; Zhou, H.; Song, H.; Ren, H.; Li, L.; Li, Y.; Zhao, D. Prevalence and Molecular Characteristics of Waterborne Pathogen Legionella in Industrial Cooling Tower Environments. Int. J. Environ. Res. Public Health 2015, 12, 12605-12617. [CrossRef]

33. Zhang, L.; Li, Y.; Wang, X.; Shangguan, Z.; Zhou, H.; Wu, Y.; Wang, L.; Ren, H.; Hu, Y.; Lin, M.; et al. High Prevalence and Genetic Polymorphisms of Legionella in Natural and Man-Made Aquatic Environments in Wenzhou, China. Int. J. Environ. Res. Public Health 2017, 14, 222. [CrossRef]

34. Nguyen, C.; Elfland, C.; Edwards, M. Impact of advanced water conservation features and new copper pipe on rapid chloramine decay and microbial regrowth. Water Res. 2012, 46, 611-621. [CrossRef]

35. Rhoads, W.J.; Pruden, A.; Edwards, M.A. Survey of green building water systems reveals elevated water age and water quality concerns. Environ. Sci. Water Res. Technol. 2016, 2, 164-173. [CrossRef]

36. Centers for Disease Control and Prevention. Legionella (Legionnaires' Disease and Pontiac Fever). History, Burden, and Trends. Available online: https://www.cdc.gov/legionella/about/history.html (accessed on 27 March 2020).

37. Centers for Disease Control and Prevention. Legionnaires' Disease Surveillance Summary Report, United States 2014-2015 Available online: https:/ / www.cdc.gov/legionella/health-depts/surv-reporting/2014-15-surv-report-508.pdf (accessed on 27 May 2020).

38. Dimitriadi, D.; Velonakis, E. Detection of Legionella spp. From Domestic Water in the Prefecture of Arta 2014, Greece. J. Pathog. 2014, 2014, 407385. [CrossRef] [PubMed]

39. Fleres, G.; Couto, N.; Lokate, M.; van der Sluis, L.W.M.; Ginevra, C.; Jarraud, S.; Deurenberg, R.H.; Rossen, J.W.; García-Cobos, S.; Friedrich, A.W. Detection of Legionella anisa in Water from Hospital Dental Chair Units and Molecular Characterization by Whole-Genome Sequencing. Microorganisms 2018, 6, 71. [CrossRef] [PubMed]

40. Mee-Marquet, N.; van der Domelier, A.-S.; Arnault, L.; Bloc, D.; Laudat, P.; Hartemann, P.; Quentin, R. Legionella anisa, a Possible Indicator of Water Contamination by Legionella pneumophila. J. Clin. Microbiol. 2006, 44, 56-59. [CrossRef]

41. Edagawa, A.; Kimura, A.; Miyamoto, H. Investigations on Contamination of Environmental Water Samples by Legionella using Real-Time Quantitative PCR Combined with Amoebic Co-Culturing. Biocontrol Sci. 2019, 24, 213-220. [CrossRef]

42. Laganà, P.; Facciolà, A.; Palermo, R.; Delia, S. Environmental Surveillance of Legionellosis within an Italian University HospitalResults of 15 Years of Analysis. Int. J. Environ. Res. Public Health 2019, 16, 1103. [CrossRef]

43. Leoni, E.; De Luca, G.; Legnani, P.P.; Sacchetti, R.; Stampi, S.; Zanetti, F. Legionella waterline colonization: Detection of Legionella species in domestic, hotel and hospital hot water systems. J. Appl. Microbiol. 2005, 98, 373-379. [CrossRef]

44. Fragou, K.; Kokkinos, P.; Gogos, C.; Alamanos, Y.; Vantarakis, A. Prevalence of Legionella spp. In water systems of hospitals and hotels in South Western Greece. Int. J. Environ. Health Res. 2012, 22, 340-354. [CrossRef]

45. Thornley, C.N.; Harte, D.J.; Weir, R.P.; Allen, L.J.; Knightbridge, K.J.; Wood, P.R.T. Legionella longbeachae detected in an industrial cooling tower linked to a legionellosis outbreak, New Zealand, 2015; possible waterborne transmission? Epidemiol. Infect. 2017, 145, 2382-2389. [CrossRef] [PubMed]

46. Smith, A.F.; Huss, A.; Dorevitch, S.; Heijnen, L.; Arntzen, V.H.; Davies, M.; Robert-Du Ry van Beest Holle, M.; Fujita, Y.; Verschoor A.M.; Raterman, B.; et al. Multiple Sources of the Outbreak of Legionnaires' Disease in Genesee County, Michigan, in 2014 and 2015. Environ. Health Perspect. 2019, 127, 127001. [CrossRef] [PubMed]

47. Schwake, D.O.; Garner, E.; Strom, O.R.; Pruden, A.; Edwards, M.A. Legionella DNA Markers in Tap Water Coincident with a Spike in Legionnaires' Disease in Flint, MI. Environ. Sci. Technol. Lett. 2016, 3, 311-315. [CrossRef]

48. Hamilton, K.A.; Hamilton, M.T.; Johnson, W.; Jjemba, P.; Bukhari, Z.; LeChevallier, M.; Haas, C.N.; Gurian, P.L. Risk-Based Critical Concentrations of Legionella pneumophila for Indoor Residential Water Uses. Environ. Sci. Technol. 2019, 53, 4528-4541. [CrossRef]

49. Legionellosis: Risk Management for Building Water Systems. Standard 188-2018. American Society of Heating, Refrigeration and Air-Conditioning Engineers (ASHRAE). Available online: https://www.ashrae.org/technical-resources/bookstore/ansi-ashraestandard-188-2018-legionellosis-risk-management-for-building-water-systems (accessed on 29 March 2020). 
50. Recognition, Evaluation and Control of Legionella n Building Water Systems, 2nd ed.; American Industrial Hygiene Association (AIHA): Fairfax, VA, USA. 2016. Available online: https://online-ams.aiha.org/amsssa/ecssashop.show_product_detail?p_ mode=detail\&p_product_serno=1047\&p_cust_id=257816\&p_order_serno=\&p_promo_cd=\&p_price_cd=\&p_category_id=\&p_ session_serno=5604896\&p_trans_ty= (accessed on 29 March 2020).

51. New York State Department of Health. Protection against Legionella. Available online: https://www.health.ny.gov/ environmental/water/drinking/legionella/ (accessed on 2 April 2020).

52. Schneiders, S.; Hechard, T.; Edgren, T.; Avican, K.; Fällman, M.; Fahlgren, A.; Wang, H. Spatiotemporal Variations in Growth Rate and Virulence Plasmid Copy Number during Yersinia pseudotuberculosis Infection. Infect. Immun. 2021, 89, e00710-20. [CrossRef]

53. Katz, S.M.; Hammel, J.M. The effect of drying, heat, and pH on the survival of Legionella pneumophila. Ann. Clin. Lab. Sci. 1987, 17, 150-156. [PubMed]

54. Nazarian, E.J.; Bopp, D.J.; Saylors, A.; Limberger, R.J.; Musser, K.A. Design and implementation of a protocol for the detection of Legionella in clinical and environmental samples. Diagn. Microbiol. Infect. Dis. 2008, 62, 125-132. [CrossRef] [PubMed]

55. Cross, K.E.; Mercante, J.W.; Benitez, A.J.; Brown, E.W.; Diaz, M.H.; Winchell, J.M. Simultaneous detection of Legionella species and L. anisa, L. bozemanii, L. longbeachae and L. micdadei using conserved primers and multiple probes in a multiplex real-time PCR assay. Diagn. Microbiol. Infect. Dis. 2016, 85, 295-301. [CrossRef] [PubMed] 